\title{
Youth, culture and religion in Italy: analysis of the situation of youth after the WYD in Krakow
}

\section{Introduction}

The experience of the World Youth Day (WYD) held in Krakow in 2016 brings us back to the roots of the preparation of Italian Youth for this world meeting. It seems important to look at the youths, their ever-changing reality, and the challenges that many of them face today, with their own eyes. This means seeing the condition of the youth from a youth perspective so as to be able to give them instruments to overcome them. ${ }^{1}$ We note that culture and religion today are undergoing various problems which provokes a general "educational emergency" of the youth. This expression educational emergency - refers to the difficulty of establishing educative rapport, for being authentic, of transmitting values and life principles to

1 Cf. A. Rosina, Introduzione. Giovani nel labirinto, in: Istituto Giuseppe Toniolo, La condizione giovanile in Italia. Rapporto Giovani 2014, Bologna 2014, p. 22. 
272 the youth. Not only for helping the individual to grow and mature, but also for taking part in building the common good. ${ }^{2}$

This reflection on the youth, culture and religion in Italy brings us to the analysis of the common project for the youth in view of their daily experiences. Further down in this article, we shall emphasize religious experience in a time of new cultural paradigms, especially in multiculturality and multireligiousity. Here, the emphasis is on the necessity showing a pastoral action that makes reference to the strategic and planning phase, oriented towards making proposals to the Italian Church, for an educative style that combines youth and vocational ministries in their mutual inclusion. One must not forget that young people are the privileged subjects of educational and formative action. They should be recognized as such by the different categories of educators: parents, teachers, religious, priests, and other educational figures. Hence, we shall emphasize the importance of pastoral attention after the WYD, to give a direction and the meaning of journeying as pilgrims in history and the contemporary culture. Based on the experience of the WYD, young people were spurred on by the words of Pope Francis to develop human and religious experiences, by accepting the interior signs of an inner work which is open to dialogue, comparison, and discernment.

\section{A common project for the Italian youth after the WYD at Krakow}

More than a year after Krakow (Poland 2016), it is worthwhile to review the rich and varied materials with which the youth have planned/prepared this great and beautiful encounter in Poland. It is not enough to simply prepare a project, it is important to review the life of the Youth after the WYD. Seven dossiers were prepared that contained many themes for deepening in various fields, and which gave all participants a wider hori-

2 Cf. Congregatio de Institutione Catholica, Educating Today and Tomorrow: A Renewing Passion. Lineamenta, World Congress on Catholic Education, Rome, 18-21 November 2015, p. 11. 
zon of a global event. At the same time, thought should be spared for the

questions and contents of what has remained after this world experience, which has offered rich promises that needs to be incarnated in daily life.

\subsection{The meaning and pastoral focus}

The theme chosen by the Pope for the XXXI World Youth Day - Krakow 2016 - was enclosed in the words "Blessed are the merciful, for they will find mercy" (Mt 5, 7). The theme inspired the event as a pilgrimage experience that immediately opens its gaze on concrete issues: ecclesial life, the world, and the culture of peoples. Pope Francis advised young people to re-read Matthew's gospel in order to make it a concrete life program ${ }^{3}$, and pastoral workers to accompany the new generation in a deep formative process. Analyzing the situation in the dioceses in Italy, one notes that not all dioceses offer the same kind of care for young people. While some use instruments and methods already rooted in the life of their parishes, others have more recent initiatives. Particularly for these dioceses, the WYD was an extraordinary occasion for meeting the youth, for aggregating them and offering them moments of spiritual formation. ${ }^{4}$ In this way, the youth, thanks to the adults activated a meaningful human encounter for evaluating and maturing ideas about life.

The WYD was also a challenge for young people to understand the "signs of the times", to understand how to live them, to activate in them a conscious participation in the life of the Christian community and in building a true humanity. Pope Francis, in the Preparatory Document of the Synod for the Youth refers to the last World Youth Day in Krakow, arguing that "things can change", especially because the young heart "can-

3 Cf. I temi della GMG 2016, in: Conferenza Episcopale Italiana. Servizio Nazionale per la Pastorale Giovanile, Progetto di Pastorale giovanile in preparazione alle 31a GMG, Quaderno 0, Un progetto comune, il significato, gli ingredienti, le attenzioni pastorali, Roma 2015, p. 7.

4 Cf. La GMG ela pastorale giovanile, in: Conferenza Episcopale Italiana. Servizio Nazionale per la Pastorale Giovanile, Progetto di Pastorale giovanile in preparazione alle 31a GMG, Quaderno 0, Un progetto comune, il significato, gli ingredienti, le attenzioni pastorali, Roma 2015, pp. 2-3. 
274 not bear injustice and cannot bend to the culture of waste, or believe the globalization of indifference" ${ }^{5}$

That is why it is necessary to value the youth resources by inviting the Church to "listen to their voice, sensitivity, faith, even doubts and criticisms" by offering innovative and responsive pastoral proposals to their "human" and "religious" feelings.

Pastoral itinerary should offer the youth a program that involves them. In the WYD, the Church was able to test the great potential of the youth, in the secular society and in the Christian community. A great number of youths participated in the WYD, who came for various motives, but above all, one must appreciate their capacity create a pastoral tool that can engage all the youth. One of the good strategies for involving the youth is the merging of one diocese with another. In this case, an Italian diocese could merge with a Polish counterpart. The Preparatory Document for the Synod on the Youth makes reference to this strategy, showing the challenges of multiculturality because "societies are increasingly multicultural and multi-religious." Moreover, "the presence of more religious traditions is a challenge, but also an opportunity to overcome relativism and prejudices towards what/who is 'different'. It is sure to create a fruitful confrontation and mutual enrichment. This new reality, a sign of our time, requires a culture of listening, respect and dialogue".

\subsection{The directions and the meaning of the pilgrimage}

Inviting young people to change involves offering them alterative and precious experiences capable of winning their attention and bring about a change of life focus. The youth will thus open themselves to new activities, to awareness and contemplation. The proposal to the youth should lead them on the track of searching or a path of discovery. A path that re-

5 Francesco, Lettera ai giovani, in occasione della presentazione del Documento preparatorio della XV Assemblea Generale Ordinaria del Sinodo dei Vescovi, in: https://press.vatican.va/content/salastampa/it/bollettino/pubblico/2017/01/13/0022/00051.html (20.06.20017). 
veals the face of the Father and his original design of Love ${ }^{6}$ towards men.

In fact, "getting on the path, together, means finding a common goal, agreeing on the pace of the steps, not to stay too far, or to run too far, because what matters is always fraternal communion."7 In this sense, "it is particularly urgent to support personal skills by putting them at the service of a solid project of growth". 8

A common path gives young people security in the face of loss, uncertainty, precariousness that are always "around the corner" in each one's life. It is therefore necessary to help them recognize and realize that life is a continuous "pilgrimage", by providing opportunities for discernment, identifying the paths of personal growth, with educational and spiritual itineraries open to religious dimension. We should reflect on the use, by our young people, of new technologies. Being "glued" to these "fast developing" tools are likely to shrink their world by dampening their desires towards "something else in flesh and bone". "Connections", often to banality, prevent a free look on the real world, made up of different cultures. The Supreme Pontiff also stressed that young people need to continue to meet each other - face to face, in order to undo distances and differences and have an encounter with peoples' worlds and peoples' religions.

These analyses are useful in setting up an education to vocation, based on the human and religious experiences of young people, in order to capture those signs that, sooner or later, may become a demand for dialogue, confrontation, and discernment. ${ }^{9}$

6 Cf. Conferenza Episcopale Italiana, Servizio Nazionale per la Pastorale Giovanile, Progetto di Pastorale giovanile in preparazione alle 31a GMG, Le direzioni, il senso del peregrinare, dell'andare e del tornare, Quaderno 1, Roma 2015, pp. 2-3.

7 Conferenza Episcopale Italiana, Servizio Nazionale per la Pastorale Giovanile, Progetto di Pastorale giovanile in preparazione alle 31a GMG, Le direzioni, il senso del peregrinare, dell'andare e del tornare, Quaderno 1, Roma 2015, p. 1.

8 Sinodo dei Vescovi, XV Assemblea Generale Ordinaria, I giovani, la fede e discernimento vocazionale, p. 29.

9 Cf. Invitare i giovani e coinvolgere tutti, in Conferenza Episcopale Italiana. Servizio Nazionale per la Pastorale Giovanile, Progetto di Pastorale giovanile in preparazione alle 31a GMG, Le direzioni, il senso del peregrinare, dell'andare e del tornare, Quaderno 1, Roma 2015, p. 15. 


\subsection{Between history and culture: organizing the journey}

The Holy Year of Mercy was the background to WYD in Krakow. It was therefore inevitable to start, precisely, from the meaning of mercy to educate young people to perceive the meaning of mercy, recognize and live it. ${ }^{10}$ Group meetings were organized to provide reflection and an exchange among young people to deepen the theme of mercy. There was also personal research on internet sites in view of a work project on the figure of Mary and some Polish saints. Poland, with its strong Marian spirituality and numerous shrines, has given young people the opportunity to retrieve the evangelical face of the Mother of Jesus, to the point of being studied in their work of learning. ${ }^{11}$ Among Polish saints, those proposed include the most recent, Faustina Kowalska, canonized in 2000 by St. John Paul II, along with two martyrs of faith, Saint Maximillian Kolbe and Blessed Jerzy Popiełuszko, both persecuted by totalitarian regimes until they gave up their life. Another significant figure in Poland is Blessed Edith Stein (Holy Theresa of the Cross), deported to the Auschwitz-Birkenau extermination camp where she died in the gas chamber. ${ }^{12}$

In this WYD, much space was given to the analysis of the current cultural context, how history, music, poetry and faith are connected. This was in order to make young people discover another way of being "Europe", and to bring the youth pilgrims to a conversion. To bring them from superficiality to the depths of the spirit, and to create bridges between the present and the past. Only in this way - by discovering our link with previous ages, and revealing the fatigue of living and believing of those who

10 Cf. Beati misericordiosi perché troveranno misericordia, Conferenza Episcopale Italiana. Servizio Nazionale per la Pastorale Giovanile, Progetto di Pastorale giovanile in preparazione alle 31a GMG. Tra fede e spiritualità. Siate misericordiosi come il Padre, Quaderno 2, Roma 2015, p. 2.

11 Cf. K. Roncalli, La figura di Maria di Nazareth, in: Conferenza Episcopale Italiana. Servizio Nazionale per la Pastorale Giovanile, Progetto di Pastorale giovanile in preparazione alle 31a GMG, Tra fede e spiritualità. Siate misericordiosi come il Padre. Beati misericordiosi perché troveranno misericordia. Quaderno 2, Roma 2015, pp. 11-14.

12 Cf. Le figure di alcuni santi polacchi, in: Conferenza Episcopale Italiana. Servizio Nazionale per la Pastorale Giovanile, Progetto di Pastorale giovanile in preparazione alle 31a GMG, Tra fede e spiritualità. Siate misericordiosi come il Padre, Quaderno 2, Roma 2015, pp. 15-24. 
lived before us - is it possible to set an educational action attentive to the emergencies of the present and the roots of the past. ${ }^{13}$

What has been expressed so far is not only relevant for young people, but also for educators, who should rethink and create relationships capable of supporting the journey of young people. The WYD has been a challenging gymnasium for all: the young as well as adult educators, sharing experiences of personal and community growth and maturity. The preparatory work helped to accomplish this important goal. It was carried out in small groups and with diocesan meetings, with attention and dedication to the youth's journey. Precious was the intelligence, the capability and the availability of the diocesan consul and the working team to put into practice these moments of formation. ${ }^{14}$

\section{The young and religious experience in the time of new paradigms}

In presenting the situation of the Italian youth after the WYD, it is best to start from the data from some research on religiosity in this postmodern society. In Italy, only one young person out of two is a believer in the Catholic Christian religion. Within the space of 15 years, the percentage dropped from $80 \%$ of those who were recognized as Catholics to $40 \%$ in $2014 .{ }^{15}$ This decline is explained by religious pluralism, but above all, a form of unidentifiable religiosity with any institutional religion. These data should be read in the light of a crisis in religious socialization involving various institutions, families, parishes, religious groups or volunteers. The crisis of faith leads to the diminution of religious contents, that

13 Cf. Prima di giungere, in: Conferenza Episcopale Italiana. Servizio Nazionale per la Pastorale Giovanile, Progetto di Pastorale giovanile in preparazione alle 31a GMG, Cracovia, la città l'occasione di condividere un mondo altro di abitare, Quaderno 4, Roma 2015, p. 2.

14 Cf. Programmare il cammino e incontrare i giovani, in: Conferenza Episcopale Italiana. Servizio Nazionale per la Pastorale Giovanile, Progetto di Pastorale giovanile in preparazione alle 31a GMG. Organizzare il percorso per muoversi col piede giusto, Quaderno 5, Roma 2015, p. 2-3.

15 Istituto Giuseppe Toniolo, La condizione giovanile in Italia. Rapporto Giovani 2014, Bologna 2014, p. 117. 
278 reveals many forms of religious analphabetism in religious language. It also leads to limiting Catholic religious practices to public rituals (weekly Eucharistic celebrations, central moments of liturgical year, etc.). In the light of the forgoing affirmations, it could be said that religious practice is affected by the cultural climate of the country, which has no clear project for the youth. Young people do not find adequate space in the public sphere and family religious socialization is still too focused only on the interior.

Alongside the crisis of institutional religiosity, new forms of sacredness are arising, with their own project of spirituality. Such projects as "to re-read, to find a new hermeneutics, to venture a new synthesis, and to make proposals from the act of believing as well as from the act of living, a new grammar of wisdom."16 Undoubtedly, the World Youth Days have used a new grammar to renew the religious proposal: starting from openness to the other. The value of being together and of the same liturgical rituals that the WYD proposes are indicators of relational character for activating relationship with God. In fact, one notes the exigency of a walk towards maturity, of discovery and the building of personal and social future. The model that seeks to remove the question of ultimate meaning of youth existence seems falsified by the events of the WYD. The interest of young people in these world meetings shows a new way of living religious experience that we can call reflective and relational. Thus disproving the argument of those who support the disappearance of religiosity without trauma. ${ }^{17}$ Reflection becomes a positive challenge, because it helps to identify the limits and contradictions of our time. It also becomes a chance to review the new world on the religious reality of the youth, which is a more concrete response to finding a harbor of awareness and mature experience..$^{18}$ Relationality, as it emerges from observations and some research, emphasizes how young people discover the positive side in everyday reality, in real and virtual spaces, to share and be

16 J. T. Mendonca, La mistica dell'istante. Tempo e promessa, Milano 2014, p. 33.

17 Cf. V. Corradi, Giovani ed esperienza religiosa: verso nuovi paradigmi, "Salesianum" 79 (2017), p. 222-228.

18 Cf. V. Corradi, Giovani ed esperienza religiosa: verso nuovi paradigmi, "Salesianum" 79 (2017), p. 225. 
constantly connected with others. ${ }^{19}$ While we acknowledge the privacy issues on the one hand, on the other hand, being in relationship implies a strong desire for involvement. The modern scenario confirms that the importance of relationship does not disappear, but faces morphogenesis and becomes more complex. This is why it is necessary to think of new categories and concepts capable of orientating youth pastoral care in Italy for an adequate understanding of religious experience in the present context.

\section{Multi-culturality and multi-religiosity in the time of youth}

Young people now live in an environment characterized by cultural and religious pluralism present in various fields: schools, universities, but also places of work or simply in everyday life. Faced with this phenomenon, they have the opportunity to confront other cultures, beliefs, norms, values, ways of living, and patterns of behavior. We cannot therefore remain indifferent in the reflection on multireligiousity and multiculturality with regard to the youth. Pope Francis has recommended that we guide young believers not only to live the faith in the "private" sphere but in serious political commitment, in the "polls", in order to form a generation of committed Christians.

Some sociologists have used the following terms to describe the new generation: atheists, unbelievers, atheistic-agnostic and indifferent. The Italian sociologist, Franco Garelli, in Small Atheists Grow: a Generation Without God?20, expresses the relationship of the new generations with religion in the Italian multicultural context. The youth live in a multicultural society; there is a link between today's culture and the crisis of identity suffered by many. These social changes inevitably challenge young people in their own personal and collective identity as human persons. Confirming this, John Paul II affirmed that "Culture is a specific way of man's existence and being. Man always lives according to a culture that

19 Cf. Abitanti della rete: giovani, relazioni e affetti nell'epoca digitale, ed. C. Giaccardi, Milano 2010.

20 Cf. F. Garelli, Piccoli atei crescono: davvero una generazione senza Dio?, Bologna 2016. 
280 is his own". ${ }^{21}$ In Italy and beyond, we talk of a "hybridization of cultures" to indicate a dynamic process of meeting, transmitting and exchanging reciprocally between cultures, resulting from a mix of peoples, thus highlighting that there is no pure culture in history. ${ }^{22}$ Many young people are opposed to cultural integration and this often curbs this process of integration. Instead, they uphold the superiority or inferiority of cultures, limiting "culture" to the civilization of the West. The comparison of languages, philosophy, literature, science, technology, and economics become reasons for evaluating other people's cultures as inferior. This is the result of broadly consolidated stereotypes often in family-based, media-backed, political and philosophical ideologies. Another problem regards cultural discrimination towards those who are different by ethnicity, skin color or religious belief. There is a stiff resistance to the phenomenon of immigration. This gives rise to discriminatory feelings towards the other, conflicting social relationships, youth gangs, ethnocentrism, xenophobia, racism, bullying in schools, etc. Hence there is an urgency of intercultural communication that confirms the right to be different, to mingle, dialogue, exchange, and promote the acceptance of plurality. ${ }^{23}$

To talk about Inter-cultural communication, we must touch the problem of cultural assimilation, especially for those young people who lose the traits of their original culture. This phenomenon gives rise to what is called "Mimetism" which characterized by the approval of cultural models of the hosting country; especially, language, way of life, dressing etc. There is also the negative consequence of cultural assimilation which is the loss of one's identity. Another taught on the problem of multiculturality and multireligiousity are the conflicts of values that are prevalent in the community and in the life of individuals. For instance, there are multiple cultures that have a different ways of perceiving marriage, family, divorce and heredity, the rapport between children and parents, be-

21 Cf. Insegnamenti di Giovanni Paolo II, Vol. 3, parte 1, Città del Vaticano 1980, pp. 1639-1640.

22 Cf. Congregazione per L'educazione Cattolica, Educare al dialogo interculturale nella scuola cattolica. Vivere insieme per una civiltà dell'amore, Città del Vaticano 2013, n. 3.

23 Cf. P. Rebughint, In un mondo pluralista. Grammatiche dell'interculturalità, Novara 2014, p. 69. 
tween boys and girls, child education, use of alcohol, cigarette drugs, cou-

ple cohabitation outside of marriage, etc. ${ }^{24}$

As regards multi-religiosity, we note that every religion represents the transcendental dimension of culture. For this reason, one can say that the young people from any country are the children of a 'religion'. In Italy, in the presence of religious pluralism, we notice an uncomfortable ignorance of the religion of others among the youth. As such, there is need for education to dialogue with the different religions of classmates, family neighbors or work colleagues. The religious formation of young people in every country, and not just in Italy, should take place in the family, but often parents have no time or skills on this subject. On the other hand, there are atheists and advocates of secularism who renounce religion in order to convince the youth with their secular ideology. One of the problematic examples is the "gender" ideology, widespread in the West but unacceptable in many non-Western cultures. According to this ideology, the individual's sexual identity is not determined by nature and biological data, but only by the subjective perception of each individual. This denies the difference and natural reciprocity between a man and a woman. ${ }^{25}$ The differences in the interreligious field also refers to the comportment of the youth aggravated by bad manners (lack of respect for people) and living conditions at the margins of every city. These are not to be immediately condemned, but need to be understood at their root causes. Religious relativism is another obstacle to overcome, as it does not only present the Catholic religion to be one of the many equally valid faiths to express the truths about God, but would like young people to come into contact with all religions so as not to be forced to follow that of their parents. It puts all religions on the same plane, showing that they all lead to the same God. A vision of this kind leads to religious syncretism, which wants to take the best out of the various religions, to mix different inclinations, religious and non-religious, thus evading an effective discernment.

24 Cf. J. Kuruvachira, I giovani nella società multiculturale e multireligiosa attuale, in: Giovani, la fede e il discernimento vocazionale. Sinodo dei Vescovi - ottobre 2018, "Salesianum", Annus LXXIX - n. 2, Aprilis-lunius 2017, p. 262.

25 Cf. Francesco, Esortazione Apostolica, Amoris laetitia, Città del Vaticano 2016, n. 56. 
In the past few years, and not only in Italy, a form of religious fanaticism has emerged as an exasperated form of defense of one's own creed, capable of reaching excesses and the utter intolerance of other religions. Faced with these challenges, it is necessary to educate young people about a balanced understanding of multilingualism and multiculturalism. Enlightened education leads changing perception about religious and cultural pluralism. Such education makes the youth to see multiculturalism as an opportunity to experience the depth of common spiritual values; namely, communion with the Absolute, prayer, songs, silence, meditation, and pilgrimage to discover the meaning of life. All young people in this way could be ambassadors of inter-culturality.

\section{Young Christians in the age of digital technology}

From the reflections already done, we can now enter into the challenge which is the systematic forgetfulness of God by Western man. The reason being the lack of time, because he wastes all of it on technology. The high systems of technology are programmed with algorithms that direct the new generations to activity. It could be argued, on the contrary, that technology is not a problem to the development of Christian vocation, because it is the expression of human will and shows the creative power of our time. It becomes dangerous when it begins to obey only economic, political or military logic; worse still, when it is used as a tool of manipulation, control, or social annihilation.

The technological revolution has invaded all aspects of life, especially of the youth. It has opened up unpredictable possibilities for communication in almost all areas of life: from school to work, leisure, politics, economics, etc. This demonstrates that "the human being [...] is structurally technical, that is: he progressively becomes human in his becoming technical." ${ }^{26}$ Knowledge and the nature of man is closely linked to humanity and creativity, that shows the society in evolution at the cultural, political and religious levels. Digital technology indicates the de-

26 C. Sini, Inizio, Milano 2016, p. 173. 
sires and visions of modern man and has taken such a dominant position

that it appears to be the only narrative element of man's life. It appears so important because for example, today, networks generate digital clusters, an informal mass that cannot assemble yet possesses a great communicative power. According to Byung-Chul Han "The digital inhabitants of the network do not get together: they lack the spirituality of gathering that produces an us. They create a peculiar gathering without a meeting, and a mass without spirituality, without soul and without spirit". In fact, new technologies change our relationship with reality by creating an environment with standardized procedures for man to be able to handle the complexity of the real world. J.M. Besnier, on the other hand, explains that accepting a technological standard is to run the risk of giving up the essence of the human being, which is language, freedom, imagination, complexity, interiority, symbols, emotions, and openness to the transcendent. The freedom we are granted is just that of using and consuming, in order to commit ourselves to meeting the needs of the economic system.

Speaking to young Christians, we must understand how digital technology is changing relationships and communication. Above all, there is the risk of their consciences falling asleep. In order to reflect on the changes in this area, you need to ask yourself what to do to educate a young man about Christian values, sacrifice, charity, faithfulness, and so on, when the digital world, while offering a rich range of positive opportunities, often focuses on those pseudo values, such as success, wealth, power, that fascinate younger people. The problem, then, is no longer about technology, but an education to a balanced use of them. In this situation, one needs to have clear ideas, otherwise the consumistic system, having reclined the masses of young people into themselves, will bring an existential void and the lack of true interpersonal relations. Existential problems and the lack of the meaning of life could become dangerous, especially in the addiction to videogames or cyber bullying. Pietro Barcellona confirms this reality when he says: "today we are what we are because we speak a language that is not an expression of our autonomy and our awareness. The colonization of the collective imagination is a characteristic trait of our time, where common sense is intrinsic to economic rationalization and 
284 the subordination of every activity to the production of goods" ${ }^{27}$ Instead, Pope Francis, in the Apostolic Exhortation Evangelii Gaudium confirms that "This economy kills" ${ }^{28}$ For this, it is necessary to give young people the motivation to see the difference between a life lived in faith in Christ and the one that rejects it.

\section{Education of the young and discernment of vocation}

The education of young people and the discernment of their vocation are two aspects to be taken seriously, because, sometimes the youths are at crossroads in the conception of a fleeting time that impedes connection with the past and a vision of "Future" and possible life project. For this reason, the youth identity should be re-elaborated in relation to categories that qualify their life awareness, especially the search for meaning, space, abstract thinking, body, sex, time, interiority, and life-project. With these categories, the youth brings life towards liberty and struggle. ${ }^{29}$

Galimberti argues that "Young people, even if they are not always aware of it, are in bad situation. And not because of the usual existential crises that cover the time of youth, but because a disturbing guest, nihilism, is acting among them, penetrating their sentiments, confusing their thoughts, weakens their soul, saddens their passions, and leaves them anemic. Families get alarmed, the school does not know what to do anymore. Only the market is interested in them to lead them on the path of entertainment and consumption, where what is consumed is their own life, which can no longer be projected into a future capable of hope and promise" 30 From this, one could deduce how the current culture results in a reduction of personal and common goals among young people. Especially normative crisis, school dropout, conflict, unemployment, risky living.

27 P. Barcellona, Parole potere. Il nuovo linguaggio del conflitto sociale, Roma 2013, p. 38.

28 Francesco, Esortazione Apostolica, Evangelii Gaudium, Città del Vaticano 2013, n. 53.

29 Cf. M. O. Llanos, Giovani, vocazione e realizzazione personale, in: Giovani, la fede e il discernimento vocazionale. Sinodo dei Vescovi - ottobre 2018, "Salesianum", Annus LXXIXn. 2, Aprilis-lunius 2017, p. 303.

30 U. Galimberti, L'ospite inquietante, Milano 2010, p. 11. 
There should be, within this culture, the fundamental steps for reinforcing youth identity and the values on which such identity is built. We can see then, that in education, there is need to improve personal relationships and creating a project of development with progressive character. The youth should be educated to self-actualization, to the realization of their potentials, to interior maturation, psychic and emotive, and in exterior behavior. According to Giugliano Vettorato, the growth of the young man implies graduality in following only one direction, passing through some losses and opportunities of life. The lack of this process translates to constant struggle to some definitive easy passage to adulthood. This identity-otherness-life project that is incomplete and weak, generates in the youth, a need for esteem and desire for protagonism ${ }^{31}$ which gives an educative and vocational response to self-realization of youths today. Thanks to educators and animators, the young man can become radical and authentic. This his integrity allows him to be effective in youth life which calls for a fundamental coherence. However, the time of youth institutes a difficult process towards the search for maturity. Various problems, choices, doubts, become constant in the existential search, in which only an educator who is rooted in values and choices, can help. ${ }^{32}$

In making choices for the youth, pedagogy of vocation would be necessary. Such pedagogy considers the youth as active subjects, capable of making a mark in history. We must therefore propose youth education that could leverage their rich resources for offering understanding and competence in their growth path, that is threatened from within and without. The realization of the Christian-human vocation could reach its fulfillment in humanity. For this reason, vocation is the actualization of the human person. Which is pronounced in a dialogue between the word of the creator and the youth, that should be accompanied by the community for creating a life-project. By doing this, the community guarantees its continuity and the dynamism of its own evolution. so that young people can achieve an identity consistent with their potential. Such ed-

31 Cfr. G. Vettorato, Giovani tra sogni e bisogni di autorealizzazione, "Note di Pastorale Giovanile" (2009) 3, pp. 26-46, 40.

32 Cf. M. O. Llanos, Giovani, vocazione e realizzazione personale, op. cit., p. 312. 
286 ucation will create a positive and stable perception, as well as being able to establish "Balances" in front of so many internal and external threats. A human-Christian vocational choice fully embodies the human being in a dialogue between the creator's word, but this must be accompanied by the community in order to realize a project of life, and guarantee its continuity and the dynamism of its evolution.

With education and vocation one can connect the pastoral problems that, today, is constituted by the dimensions of professed faith and lived faith. Because of this, there is need for a radical and personal authenticity in the Christian life. The World Youth Day is a good good example, where many young people responding to the invitation of the holy father to come and share experiences with youths from other places, in a holiday climate and with openness. ${ }^{33}$ During these events, the youth could welcome constant and conscious itinerary that leads to initiatives of encounter and the deepening of the evangelical actions. The consequence of such encounter could provoke a more effective conquest in the vocational and educative field. Pastoral and educative interventions should help the young in confronting religious and cultural pluralism through effective and serious reasoning on the experience of the community. The response to the vocational question, which may be a little confusing in our time, requires essentially community openness. In reality, as we have seen in the analysis of the WYD, the youth identify with Christian proposals that is rooted in experience in which they are involved. This renders them able to take positions in respect to the environment. Vocational ministry therefore brings the youth closer to Christ, they feel the presence of God on their journey (Cf. Gal 2, 20). The encounter with Christ offers both the pastoral agent and the youth the possibility of evangelizing. Vocational ministry therefore welcomes a new man, for this reason, the pastoral agent charged with vocational ministry should orient towards the reality of the youth and the proclamation of the gospel. This means, on the one hand, listening to the voice Christ; and on the other, listening to the social-cultural context of the youth. Uniting both parts of vocation, we find

33 Cf. Conferenza Episcopale Italiana. Servizio Nazionale per la Pastorale Giovanile, Progetto di Pastorale giovanile in preparazione alle 31a GMG, Quaderni 0-6, Roma 2015. 
the conclusive objective of the human life-project, which is joy and happiness. Yet it should not be forgotten that the ethical dimension and the ministry of life-project, is the love which leads to self-donation. The vocational ministry should therefore generate a project with love which is the climax of the fullness of man. ${ }^{34}$

Education and vocation therefore takes into consideration, the reciprocal process between the possibility of the individual in his cognitive, biological, sexual aspects, and between the social ambient that offers such possibilities. The service of vocational ministry aims to lead every young person to greater development. Therefore every educator should work to find an inclusive vision of the complexity of the elements that constitute youth identity. ${ }^{35}$

\section{Expectations and hope of the young and the Italian Church}

The hopes and expectations of Italian youth requires not only physical strength but also, spiritual. One year after the WYD in Krakow, the Holy Father, like Evangelist John, places the youth at the center of the Church's relflection: "I write to you young people because you are strong and the word of God remains in you and you have conquered the Evil One" (1 Jn 2,14). The Pope, writing to the youth, announced a Synod for them: "Youth, Faith and Discernment of Vocation", a path of reflection for presenting the plan of God's in the life of every young person and in his spiritual accompaniment. This reflection questions the Church and the entire society, and awakens the consciousness of adults. ${ }^{36}$

With the proposal of the synod, the youth becomes protagonists, since the transmits to the youth the following message: "I want to take care of you because you are special!" Young people of parishes are important, but this also goes to young people from other religions. Here emerges the meaning of vocation as linked to God's plan for every person the condition

34 Cfr. Giovanni Paolo II, Lettera Enciclica Redemptor Hominis, "Acta Apostolicae Sedis" 71 (1979), pp. 257-324, n. 10.

35 Cf. M. O. Llanos, Giovani, vocazione e realizzazione personale, op. cit., p. 326.

36 Cf. M. Anselmi, Attese e speranze, "Note di Pastorale Giovanile" 2 (2017), pp. 20-21. 
288 of which varies from one country to another and leading to many controversies. But precisely in Evangelii Gaudium, Pope Francis concretizes, saying: "Young people, in their usual structures, often find no answer to their anxieties, necessities, problems and injuries. We adults have to listen to them patiently, understand their concerns or their demands, and learn to talk to them in the language they understand. This may be why educational proposals do not produce the hoped fruits." ${ }^{37}$ In fact, sociological investigations present a panorama of problems with regard to the youth: discomfort, fragmentation, transgression, crisis, reflux, marginalization, and delinquency. Unfortunately, rarely do they present a positive description the youth, or seek to lead them to hope, values, generosity, desires, and dreams. At any rate, one does not expect the social sciences to include pastoral proposals. The youth must have a healthy rapport with the Church, and at the same time, the Church must make them feel loved throuth patient listening, an empathy, interest. ${ }^{38}$ Without this effort, the Italian Church elaborates only theoretical pathways that will remain only on paper, because they cannot attract the interest of the youth.

It has always been expected that the youth should be made protagonists in various sectors of life. It would be fundamental to underline, especially, attention to the relation of adults with youths in difficulty: those having issues with disappointments, responsibility etc. There is need to rediscover the role of the Church as an educative community, and to rediscover the Church in its universality, where everyone is his/her brother's keeper. Only in this type of Church can the youth learn to grow, feeling loved and giving love. In this sense, the youths can be real protagonists if there is an effort to listen and dialogue with them without presumption.

There are so many young people involved in proclaiming the gospel. This activity - as we saw in the WYD where youths from all parts of the world were protagonists - needs to be appreciated. Among them, no one is excluded, but they need to be assisted so that they can be encouraged and have more confidence. In that sense, it is important to rediscover the value of spiritual maternity and paternity, as an educational significance

37 Francesco, Esortazione Apostolica, Evangelii Gaudium, n. 105.

38 Cf. M. Anselmi, Attese e speranze, op. cit., p. 21. 
of the Church and society. This will make young people to be like the "morning sentries", busy, active, enthusiastic, and lovers of life.

\section{Conclusion}

The experience of the WYD in Krakow in 2016 recalls the roots of the preparation of Italian Youth for the World Summit. Today's religion and culture are going through various problems giving rise to a widespread "educational emergency" of young people at a time of new cultural paradigms, especially in multi-culturality and multi-religiosity. At this point, it is necessary to show the pastoral action that went into the preparatory phase, in order to examine the educative style of the Italian Church that recognizes the inclusion of youth and vocational ministry. For this reason, young people in the maturing process are to be recognized by different categories of educators as subjects whose identity needs to be re-elaborated in relation to the search for meaning, space, abstract thinking, body, sex, time, interiority, and life project. These characteristics brings not only the aspiration to improved existential wellbeing of the youth, but can open the youth to the profound vocational aspiration that characterizes their lives.

Each WYD proposes a human and religious journey of the young people following the Pope's invitation, and with a look towards ecclesial life, religion, and cultures of peoples. The reflections proposed in this article urges all adult educators to create relationships capable of motivating, supporting and guiding the path of all young people. The WYD is a lifelong gymnasium for all - youth, adults, educators, lay people and priests - to share experiences of growth and maturity. The great number of young people present in these meetings are indications of all the youthful potentialities in the secular society and in the Christian community.

Calling the Youth to walk "together" means, not neglecting the cultural and social changes that produces disorientation, uncertainty and precariousness. It is necessary, therefore, to help the recognition and realization of the youth's life as a "pilgrimage" by offering opportunities for discernment, identifying paths of personal growth, and discovering religious values as inspiration for educational and spiritual itineraries. In 
290 fact, the great expectation is for young people to become protagonists in various areas of life. It is therefore necessary to rediscover the role of the Church from an educational point of view, and from the perspective of an educating community.

The World Youth Days therefore brings with it a project of a new language, which seems to be a passage from the diffusion of reflection and relationship to openness towards the other. The value of being together and of the same liturgical rituals, have relational characteristics capable of activating relationship with God. This meeting also helped Pope Francis who, in the Preparatory Document for the Synod, refers to the last WYD in Krakow where he wanted to hear that "things can change", especially because the young heart "cannot bear injustice, cannot bend to the culture of waste, or believe the globalization of indifference." ${ }^{39}$ It is true that youth is a challenging period of life, because various problems, choices, and doubts are constant in their existential search. Only an educator that is radical in values and authentic in choices can help in this search. These educators should help young people who systematically forget God, usually for the lack of time, which they waste on technology. Technology appear dangerous today, as they are becoming the instrument of manipulation, control, or even social annihilation. For this reason, the identity of the youth should be re-elaborated in relation to categories that qualify their vital awareness, especially the search for meaning, space, abstract thinking, body, sex, time, interiority and life-project. These characteristics bring, not only the aspiration to the well-being of their existence, but can open them to the profound vocational aspiration that characterizes their life.

\section{Bibliography}

Abitanti della rete: giovani, relazioni e affetti nell'epoca digitale, ed. C. Giaccardi, Milano 2010.

Anselmi M., Attese e speranze, "Note di Pastorale Giovanile” 2 (2017), pp. 20-23.

39 Francesco, Lettera ai giovani, in occasione della presentazione del Documento preparatorio della XV Assemblea Generale Ordinaria del Sinodo dei Vescovi. 
Barcellona P., Parolepotere. Il nuovo linguaggio del conflitto sociale, Roma 2013.

Beck U., II Dio personale. La nascita della religiosità secolare, Bari 2008.

Besnier J.-M., L'uomo semplificato, Milano 2013.

Castellucci E., Chiesa e giovani. Parola di vescovo, "Note di Pastorale Giovanile" 2 (2017), p. 27-31.

Conferenza Episcopale Italiana. Servizio Nazionale per la Pastorale Giovanile, Progetto di Pastorale giovanile in preparazione alle 31a GMG, Quaderni 0-6, Roma 2015.

Congregatio de Institutione Catholica, Educating Today and Tomorrow. A renewing passion. Lineamenta, World Congress on Catholic Education, Rome, 1821 November 2015, Città del Vaticano 2015.

Congregazione per l'Educazione Cattolica, Educare al dialogo interculturale nella scuola cattolica. Vivere insieme per una civiltà dell'amore, Città del Vaticano 2013.

Corradi V., Giovani ed esperienza religiosa: verso nuovi paradigmi, „Salesianum” 79 (2017), p. 210-230.

Francesco, Esortazione Apostolica, Amoris laetitia, Città del Vaticano 2016.

Francesco, Esortazione Apostolica, Evangelii Gaudium, Città del Vaticano 2013.

Francesco, Lettera ai giovani, in occasione della presentazione del Documento preparatorio della XV Assemblea Generale Ordinaria del Sinodo dei Vescovi, https://press.vatican.va/content/salastampa/it/bollettino/pubblico/2017/01/13/0022/00051. html (20.06.2017).

Galimberti U., L'ospite inquietante, Milano 2010.

Garelli F., Piccoli atei crescono. Davvero una generazione senza Dio?, Bologna 2016.

Giovanni Paolo II, Lettera enciclica Redemptor Hominis, "Acta Apostolicae Sedis" 71 (1979), pp. 257-324.

Han B. Ch., Nello sciame. Visioni del digitale, Roma 2015.

Istituto Giuseppe Toniolo, La condizione giovanile in Italia. Rapporto Giovani 2014, Bologna 2014.

Kuruvachira J., I giovani nella società multiculturale e multireligiosa attuale, in: Giovani, la fede e il discernimento vocazionale. Sinodo dei Vescovi - ottobre 2018, "Salesianum" Annus LXXIX - n. 2, Aprilis-Iunius 2017, pp. 257-278.

Llanos M. O., Giovani, vocazione e realizzazione personale, in: Giovani, la fede e il discernimento vocazionale. Sinodo dei Vescovi - ottobre 2018, "Salesianum", Annus LXXIX - n. 2, Aprilis-lunius 2017, pp. 303-327.

Mendonca J. T., La mistica dell'istante. Tempo e promessa, Milano 2014.

Rauti I., Generazioni senza voce, "Note di Pastorale Giovanile” (2012) 4, pp. 5-6.

Rebughint P., In un mondo pluralista. Grammatiche dell'interculturalità, Novara 2014.

Roncalli K., La figura di Maria di Nazareth, in: Conferenza Episcopale Italiana. Servizio Nazionale per la Pastorale Giovanile, Progetto di Pastorale giovanile in preparazione alle 31a GMG, Tra fede e spiritualità. Siate misericordiosi come il Padre. Beati misericordiosi perché troveranno misericordia, Quaderno 2, Roma 2015, pp. 11-14. 
292 Rosina A., Introduzione. Giovani nel labirinto, in: Istituto Giuseppe Toniolo, La condizione giovanile in Italia. Rapporto Giovani 2014, Bologna 2014.

Sini C., Inizio, Milano 2016.

Sinodo dei Vescovi, XV Assemblea Generale Ordinaria, I giovani, la fede e discernimento vocazionale. Documento preparatorio, Bologna 2017.

Vettorato G., Giovani tra sogni e bisogni di autorealizzazione, "Note di Pastorale Giovanile" (2009) 3, pp. 26-46. 